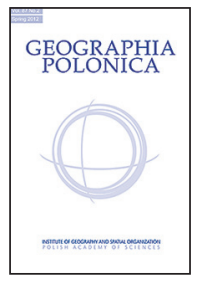

\title{
REURBANISATION IN A POST-SOCIALIST CITY: SPATIAL DIFFERENTIATION OF THE POPULATION IN THE KRAKÓW AREA (POLAND)
}

\section{Sławomir Kurek - Mirosław Wójtowicz}

Institute of Geography

Pedagogical University of Kraków

Podchorążych 2, 30-084 Kraków: Poland

emails: sgkurek@up.krakow.pl • miroslaw.wojtowicz@up.krakow.pl

\begin{abstract}
A process of reurbanisation associated with the resurgence of inner-city housing has been observed in Western Europe since the 1980s. Nowadays this trend is not only seen in large urban areas but also in the medium-sized towns and cities of Eastern Europe. However, there is still a lack of empirical research on the spatial variation of the population change within such cities. This paper explores the process of reurbanisation in the city cores and its underlying dynamics against demographic changes, using the city of Kraków (Poland) as an example.
\end{abstract}

\section{Key words}

reurbanisation • second demographic transition • post-socialist city • spatial disparities • Kraków Poland

\section{Introduction}

The decline of many large cities which occurred in western Europe during the 1960s-1980s was followed by population gains in the urban core (Friedrichs 1993; Cheshire 1995; Champion 2001; Couch \& Fowles \& Karecha 2009; Fol \& CunninghamSabot 2010). Not only do the largest urban centres illustrate this trend but it has also been evolving in medium-sized cities such as Leipzig, Bologna or León as well as in the cities of East Central Europe like Gdańsk, Brno or Ljubljana (Buzar et al. 2007a, b;
Kabisch et al. 2008; Bouzarovski et al. 2010; Haase et al. 2010, 2012b; Grabkowska 2012). The resurgence of inner-city housing has been discussed since the 1980s under the concept of reurbanisation. It describes the tendency of inner-city areas to regenerate by means of declining out-migration and the encouragement of the present residents to stay as well as the influx of new residential groups (Haase et al. 2008). The reurbanisation stage in an evolutionary model of city development emerged as a concept in urban research in the 1980s (Hall \& Hay 1980; van den Berg et al. 1982). The subsequent phases 
of development of functional urban areas (divided into a core area and its hinterland) include urbanisation, suburbanisation, deurbanisation and reurbanisation. During the first stage, the population in the central city grows faster than in its periphery; in the second phase, suburbanisation leads to faster growth of the periphery and the decentralisation of businesses and residences, while the whole metropolitan area continues to expand. In the deurbanisation phase, economic activities and residents spread beyond the borders of the metropolitan area, leading to shrinkage of the urban agglomeration as a whole. Finally, the reurbanisation phase shows growing population in the city core in absolute or relative terms (Fol \& Cunningham-Sabot 2010). In other words, reurbanisation can be seen as an increase in the population within the administrative boundaries of a city after a long period of decline (Haase et al. 2017). The main indicator of reurbanisation is population change which can also be interpreted with respect to household changes, economic growth or investment attractiveness (Beauregard 2009; Turok \& Mykhnenko 2007). In recent years, however, the concept of cyclical urban development has been criticised as a greater diversity has been observed in the evolutionary models of cities, e.g. in several European urban regions two stages occurred simultaneously, namely suburbanisation and reurbanisation or deurbanisation and reurbanisation. It is further argued that the stages in the van den Berg model do not necessarily lead to cyclical development and that the shifts between the four stages do not appear in sequential order (Turok \& Mykhenko 2007; Buzar et al. 2007b; Kabisch \& Haase 2011; Kabisch et al. 2012). As early as in 1995, Cheshire noted that European cities were no longer homogeneous: during the 1980s nearly half of the city centres in Northern Europe were shown to be regaining population. According to $A$. Haase et al (2012) reurbanisation at the macro-level is a process of relative or absolute increase in population in the city core compared to adjacent areas. On the other hand, at the meso-level, reurbanisation is a process of stabilisation of the inner city as a residential site after a longer phase of decline

The main driving force of reurbanisation is the demographic change associated with the theory of the second demographic transition (van de Kaa 1987; Lesthaeghe 2010). On one hand, this can be related to urban decline as one of the signs of the SDT is a drop of fertility below replacement level and marriage decline as well as postponing births and an increase in childlessness. However, it can also contribute to repopulation as it is quite a young population which primarily dominates in the migration flows to the inner city (Kramer \& Pfaffenbach 2016). The growing share of smaller and single-person households, the rising rate of women in the workplace, the growing number of dual-income households remaining childless for longer periods are all observed as important factors of the reurbanisation of city centres (Ogden \& Hall 2000; Buzar et al. 2007b; Steinführer \& Haase 2007). Therefore, some authors provide a central explanatory background to these developments as a key element in the evolution of modern cities, examining expanded growth of non-conventional household types and the lifestyle differentiations associated with these (Haase et al. 2008). The relationship between the demographic trends and the transformation of urban spaces with an intensive debate on the 'renaissance of cities', the resurgence of the inner city or in other words, on reurbanisation, has been accentuated (e.g., Champion 2001; Herfert 2002; Buzar et al. 2005; Kuhn 2007; Glatter \& Siedhoff 2008; Haase 2008; Fol \& Cunningham-Sabot 2010).

In urban studies of city centres, the process of gentrification has frequently been investigated. Initially, the term gentrification was used to describe social change and the physical improvement of housing stock in inner London leading to the displacement of the working class by a middle-class population (Glass 1964). Later, the definition of gentrification evolved around three explanations: an economic switch from manufac- 
turing industries to service-based sectors; changing cultural preferences and working patterns (e.g. dual professional households) as well as the growing rent gap between the potential value of inner city land and the undervalued housing stock (Hamnet 2003). Ouředníček et al (2015) perceived the gentrification process as different from reurbanisation because it affects only certain parts of the inner city and it is tied to certain social groups.

In recent decades, the process of suburbanisation has been very intensive in postsocialist countries, which was a result of the socio-economic transition. However, in recent years more and more studies have drawn attention to the process of inner-city regeneration related to attractive housing locations with the availability of an offer of cultural and entertainment services. In recent decades the city cores in Central Eastern Europe were in a deplorable condition, with the processes of population ageing taking place and selective outmigration. During the post-socialist transition, increased suburbanisation has led to further outmigration (Haase et al. 2012a). Nonetheless, the socio-demographic shift associated with the second demographic transition, diversification of lifestyles and the rise of non-traditional households has provided new opportunities of residential change (Grabkowska 2012).

In spite of the fact that the process of reurbanisation has gained increasing attention among urban scholars, there is still a lack of empirical research on the spatial variation of population change within such cities as well as an insufficiency of data about the effects of reurbanisation on residential mobility and housing preferences (Bouzarovski et al. 2010; Haase et al. 2010). Haase et al (2017) indicated that reurbanisation has gained importance as suburbanisation has weakened and the inner city has offered refurbished housing stock attractive to young people. Furthermore, the link between demographic behaviour and urban development by means of analysing inner-city residential shifts and their interconnection with demographic and household changes has remained underresearched (Steinführer \& Haase 2007). This paper explores the process of reurbanisation in city cores and its underlying dynamics against demographic changes. Using the city of Kraków as an example, empirical findings have been presented which are embedded in the discussion of the short-term and medium-term implications of demographic processes for urban development in CentralEastern European cities. More specifically, we are seeking to investigate: (1) how population trends have changed over the past two decades; (2) if there is a demographic rejuvenation of inner-city areas in quantitative terms, including the relative growth of population and the diversification of age composition; (3) what are the driving forces behind the increasing residential attractiveness of selected inner-city areas in the City of Kraków. The data has been prepared by the Department of Data Analysis and Monitoring of the City of Kraków and it has been published on the StatKraK portal which was created to establish a permanent supportive City-management instrument. It includes statistical data relating to the city as a whole and divides the city into 18 local government districts and 141 urban enumeration districts (hereinafter referred to as wards).

\section{Study area}

Kraków is the second largest city in Poland taking into consideration its population as well as its role as an important cultural, educational, scientific and economic centre. Situated on the Vistula River in the southern part of the country, it is the capital of the historic region of Małopolska and its Old Town is included in the UNESCO World Heritage Site List attracting crowds of tourists from all over the world. After the Second World War, as a result of the construction of the Nowa Huta metallurgical complex (which was incorporated into Kraków in 1951), the city became an important industrial centre. In the 1970s, the company employed 40,000 people (Płaziak 2014) and other 
companies, such as chemical, pharmaceutical, machine, electro-technical and food industries developed as well. Before the end of the era of real socialism, approximately 65 thousand people commuted to Kraków (Zborowski 2009). After 1989, the socioeconomic transformation, moving from a centrally-controlled economy to a marketbased economy, accompanied by legal and institutional changes, deeply influenced the pace and scale of transformations in the functional-spatial structures of cities. In Kraków, the effects of the above-mentioned changes were a decrease in employment in industry, privatisation, the restructuring and windingup of out-dated industrial plants, and the development of services and the real estate market. In the metallurgical complex in Nowa Huta, the number of employees fell to 3,000 (Brzósko-Sermak et al. 2017) and the plant was taken over by Arcelor-Mittal Steel. Some industrial plants, such as the Wawel Confectionery Plant and Vistula clothing company, were relocated into the hinterland (economic suburbanisation, Kurek et al. 2014a). Postindustrial areas were transformed into service and trade areas (Zakopianka Shopping Centre on the site of the former Solvay chemical plant, Galeria Kazimierz on the site of the meat plant, Galeria Krakowska on the west side of the Main Railway Station). The political and economic transformation also influenced urban transformation in Kraków. The construction of high-rise housing estates ceased in the 1990s, and the predominant form of residential development has been multi-family 3-, 4- and 5-storey housing complexes (Motak 2007). The number of single-family houses that have been built has also increased including both terraced houses within residential complexes as well as detached houses. The number of new apartments occupied in Kraków annually, in the years from 1995 to 2009, increased from 1,677 to 10,344 , and in the period from 1995 to 2013 the dwelling stock increased from 243.4 thousand to 346.4 thousand apartments. The quality of housing infrastructure has also improved - in the years from
1995 to 2013 - the average floor area per capita increased from 17.0 to 26.3 square metres and the average number of individuals in a single apartment decreased from 3.1 to 2.2 (Kurek et al. 2014b).

The spatial dimension of the demographic and social transformations of Kraków which have taken place over recent years are characterised by the gradual deconcentration of the population caused by the suburbanisation process (Kurek et al. 2013). This leads to clear displacement of the population, not only to the municipalities in suburban areas but also to the peripheral urban districts subject to a construction boom. Until the beginning of the 90s, the areas included in the administrative boundaries of the cities in the post-war period were distinguished by a relatively low level of urbanisation, and in many cases by their rural nature (Mydel 1994, 1996). After the economic transformation of the first half of the 1990s and with the development of the real estate market, some of these districts, mainly the ones with the most attractive location in relation to the transport network, noted a rapid increase in residential development and the population growth associated with this. Residents moving from the central areas of the city, seeking to improve their housing conditions or displaced from these areas as a result of the replacement of residential functions with other forms of activities, constituted a significant part of this. Consequently, this led to clear shifts in the spatial redistribution of the residents of Kraków and changed the distribution of their demographic age as well (Wójtowicz et al. 2014; Kurek et al. 2017).

In administrative terms, Kraków is divided into 4 registration units (Śródmieście, Nowa Huta, Krowodrza and Podgórze) consisting of a total number of 18 districts and 141 urban wards (see Annex). Wards 1 to 9 are part of the Stare Miasto district and wards 1-18 are located in the registration unit of Śródmieście. Furthermore, the eastern part of the city is Nowa Huta (as previously mentioned, originally a separate town built as housing resources close to the steel plant) 
including the urban wards 99 to 141 (wards 117 to 128 constitute the central and - at the same time - oldest part of Nowa Huta). The north-western part (Krowodrza - wards 19 to 50), the south and south-west part (Podgórze - wards 51 to 98) include prefabricated large-block housing estates and closer to the city limits - modern multi-family housing complexes as well as estates of individual family dwellings and terraced houses. Furthermore, in the western part of Kraków, there are green and recreational areas (e.g. ward no 48 - Wolski Forest), and along the main outgoing roads there are many large surface area retail trade and service centres (Fig. 3).

\section{Population development}

The spatial layout of the city of Kraków briefly mentioned above has an impact on its sociodemographic diversity. In the years from 1988 to 2016, the population of Kraków increased by $2.5 \%$ noting an insignificant decline in the early 1990s and the beginning of the 21st century (Fig. 1). Since 2008 there has been a steady increase in the population reaching
765.3 thousand in 2016. It should be noted that the number of residents of Kraków may be underestimated due to the number of temporarily resident students and those who have not registered a change of residence. In the period from 1995 to 2006, the population of Kraków recorded a natural population drop and since 2007 the trend has been reversed, and the number of births insignificantly exceeds the number of deaths. The values of the general fertility rate slightly exceeded 1.000; in the period from 2002 to 2015 its value increased only from 1.006 to 1.185 . In 2016, almost two thirds of all births occurred to mothers aged 30 and over, which confirms a progressive postponement process, one of the signs of the second demographic transition (www.stat.gov.pl). The net migration rate for Kraków was positive in the period from 1995 to 2015 and the aggregated migration rate for the period from 1990 to 2012 was 21,000 people despite a significant outflow of population to the suburban zone (Kurek et al. 2013). In recent years, the migration rate is higher than the population growth rate. According to research conducted by Zborowski \& Soja (2009), there is

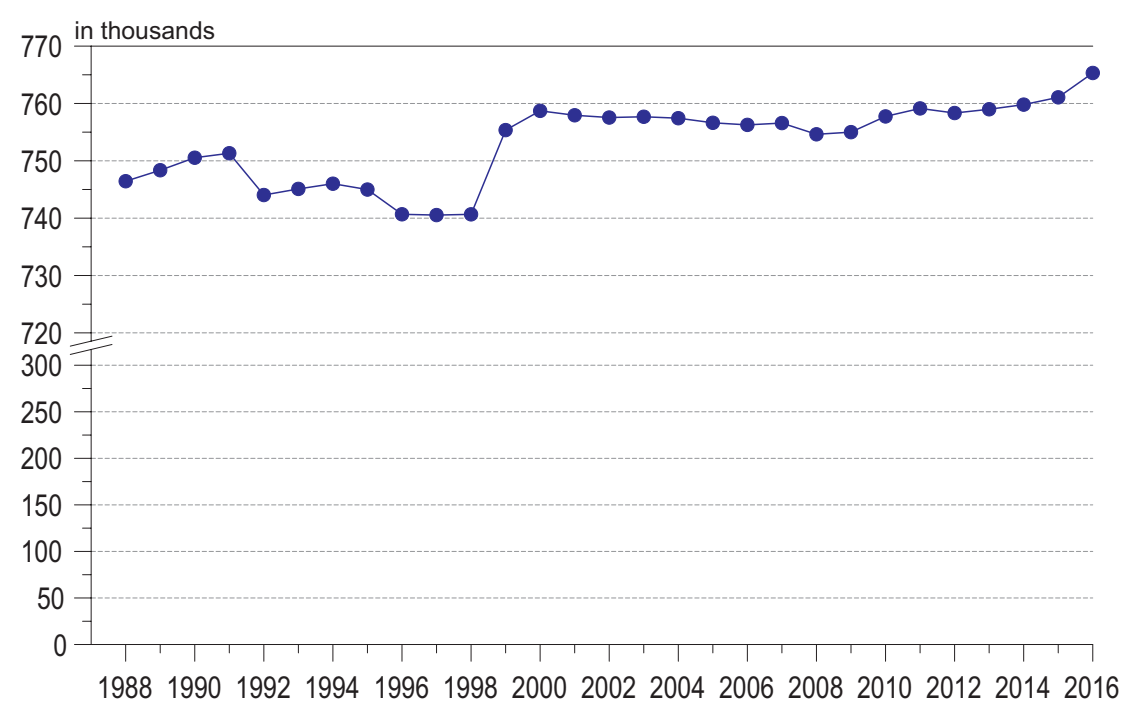

Figure 1. Changes in the population of Kraków over the years 1988-2016

Source: authors' analysis based on data from the Central Statistical Office 
a considerable influx of young people (singles and families) into the downtown areas and it is larger than the settlements of largeblock housing estates and peripheral parts of the city. This significant influx of young people can be attributed to an increase in the level of studentification of the city and the development of rental housing. During the census period of 2002-2011, the number of households in Kraków increased from 307 to 321 thousand, while the average number of people in the household decreased from 2.37 to 2.32 (UKS 2003, 2014). At the same time, the share of single-person households did not change, the number of two-people households increased whereas the percentage of three-people and larger households decreased (Fig. 2). This trend is consistent with the changes in the light of the second demographic transition, where - despite the increase in the number of households their average size decreases. There was also an increase in the proportion of childless families (couples or partnerships); from 25\% to $29 \%$ of all families (UKS 2003, 2014).

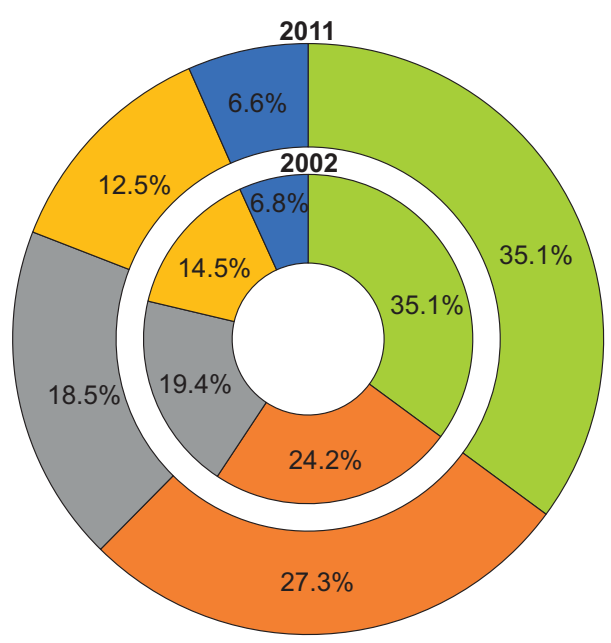

Household size (person)

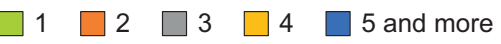

Figure 2. Household size in Kraków (in percentages of total households) in the years 2002 and 2011

Source: authors' analysis based on data from UKS (2014).

\section{Spatial disparities}

As regards the spatial distribution of population in the years from 2007 to 2014, slightly more than $50 \%$ of the urban wards examined recorded an increase in total population and the greatest changes in population size were seen on the outskirts of Kraków (Fig. 3), which was related to internal suburbanisation and a higher rate of building construction activity by developers in areas with a large availability of vacant plots and cheaper prices as compared to the city centre. In particular wards, there was an over two-fold increase in population growth. Downtown areas noted a decrease in population size, with the exception of wards 11-13 located in former industrial areas with developed commercial and service infrastructure (Kazimierz Shopping Mall) as well as proximity to walking areas (Vistula Valley) and Kazimierz (the former Jewish district and, currently, a centre of cultural life in the city). The cultural qualities and availability of infrastructure influence how attractive these areas are to settlement despite the high prices of apartments. Here, we are dealing with the phenomenon of gentrification where enclaves appear in which people with a relatively high material status become resident. The process of gentrification and reurbanisation must be distinguished at this point as the first one involves the flow of the richer middle class to degraded areas whereas the features of the second one include diversification of the flow of people, both in terms of wealth and the structure of households (Haase D. et al. 2008; Haase A. et al. 2010, 2012b). Thus, contemporary reurbanisation is not limited to gentrification, but rather encompasses a range of social groups (Ogden \& Hall 2000; Buzar et al. 2007). Population growth was also marked by the neighbouring Zabłocie ward (no. 90), located on the other side of the Vistula River where industry had dominated until the end of the 1980s. Since the late 1990s, activities have been taking place designed to promote regeneration of this district, which today is one of the most dynamically developing areas 


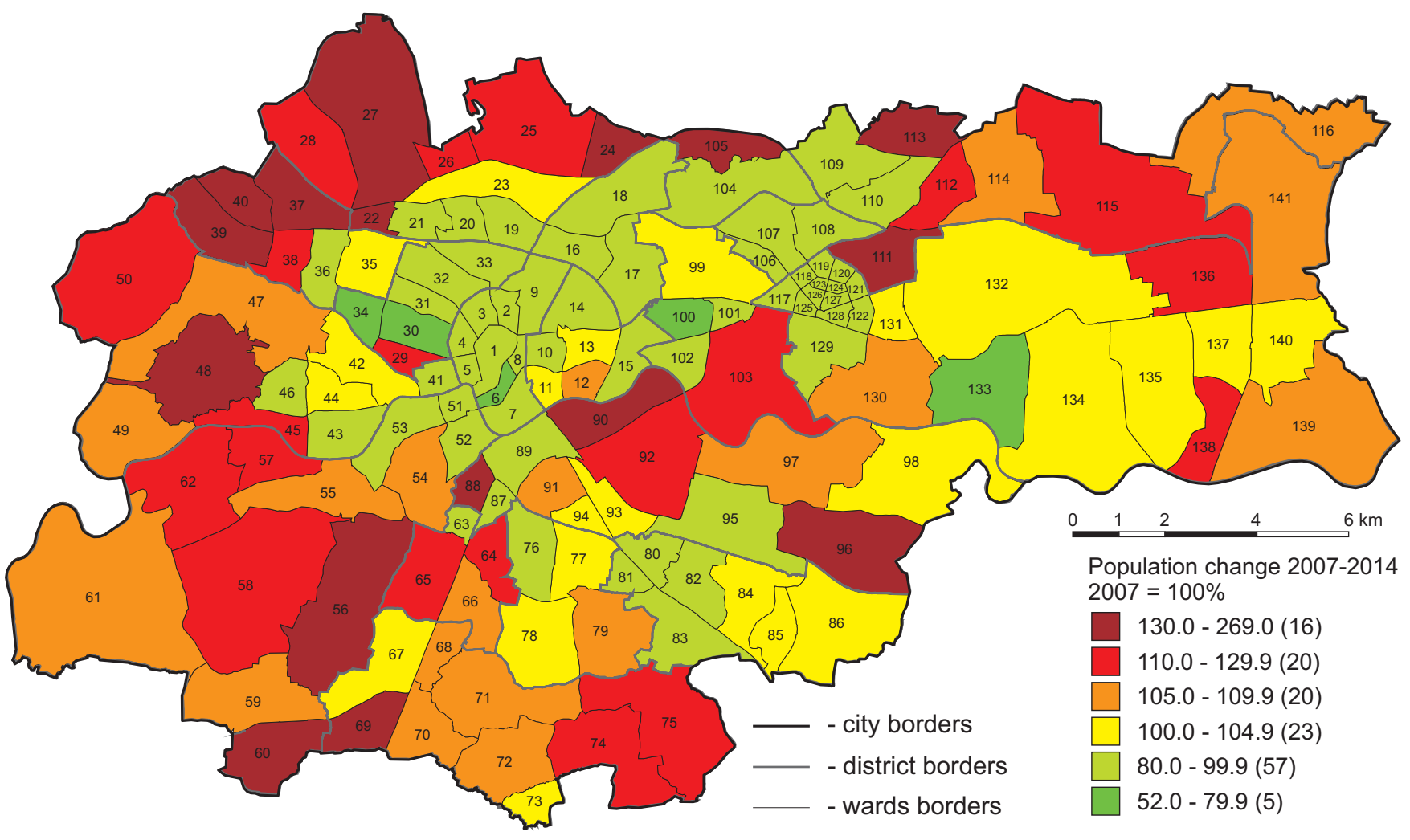

Selected urban wards:

1-9 - Stare Miasto (Old Town), 19-50 - Krowodrza, 117-128 - central and oldest part of Nowa Huta

Figure 3. Population change in urban wards in Krakow in the years 2007-2014 (2007=100). Complete list of administrative units in the Annex

Source: authors' analysis based on data from the Municipality of Kraków, City Government Office (the same applies to Figs. 4-11). 
of Kraków. Apart from its residential function, it plays an important cultural function (branches of the Historical Museum of the City of Kraków and the Museum of Contemporary Art have been opened on the site of the former Oskar Schindler factory). Furthermore a higher vocational school was established in this district and its accessibility was also improved with the opening of a bridge connecting Zabłocie with Śródmieście and a footbridge to Kazimierz. The decline of population size also affected housing estates constructed of large prefabricated blocks (e.g. no. 80-83 located in the southern and northern part of the city), in addition to the downtown area.

The analysis of the spatial distribution of changes in the age structure of the population of Kraków has shown great variation. Four economic age groups defined according to the Central Statistical Office classification (pre-production group: 0-17 years of age, mobile production group: 18-44 years of age, non-mobile production group: $45-59$ years of age for women and 45-64 years of age for men and post-production group: 60/65 years of age and more). In the youngest age group, 72 out of 141 wards recorded an increase in the population size of this category over the years from 2007 to 2014, mostly in the housing estates located on the outskirts of the city, and this is related to high rates of construction activity in recent years and internal suburbanisation (Fig. 4). In 15 urban wards the rate of increase exceeded $50 \%$, by comparison - in the period examined - the total population growth for the whole of Kraków did not exceed $0.5 \%$. From all the age groups analysed, the largest increase of all the age categories took place in the group under 18 years of age and affected only 27 wards (19\% of the total number). Close to the downtown areas, the increase in the number of children and adolescents was mainly in the post-industrial districts, e.g. Zabłocie (no. 90), Grzegórzki Północ (no. 13), Ludwinów (no. 52). This is a result of the succession of functions - industrial plants that are on the verge of bankruptcy or relocated beyond the city release attractive land for housing development. New flats were rapidly built in these areas, which was conducive to the influx of new residents setting up families. Within these regions, there are apartments for middle-income residents, although there are luxury apartments offering a view of Wawel Hill whose price per square metre is often twice the average price for Kraków.

The spatial image of the increase in population size of the young working-age popula-

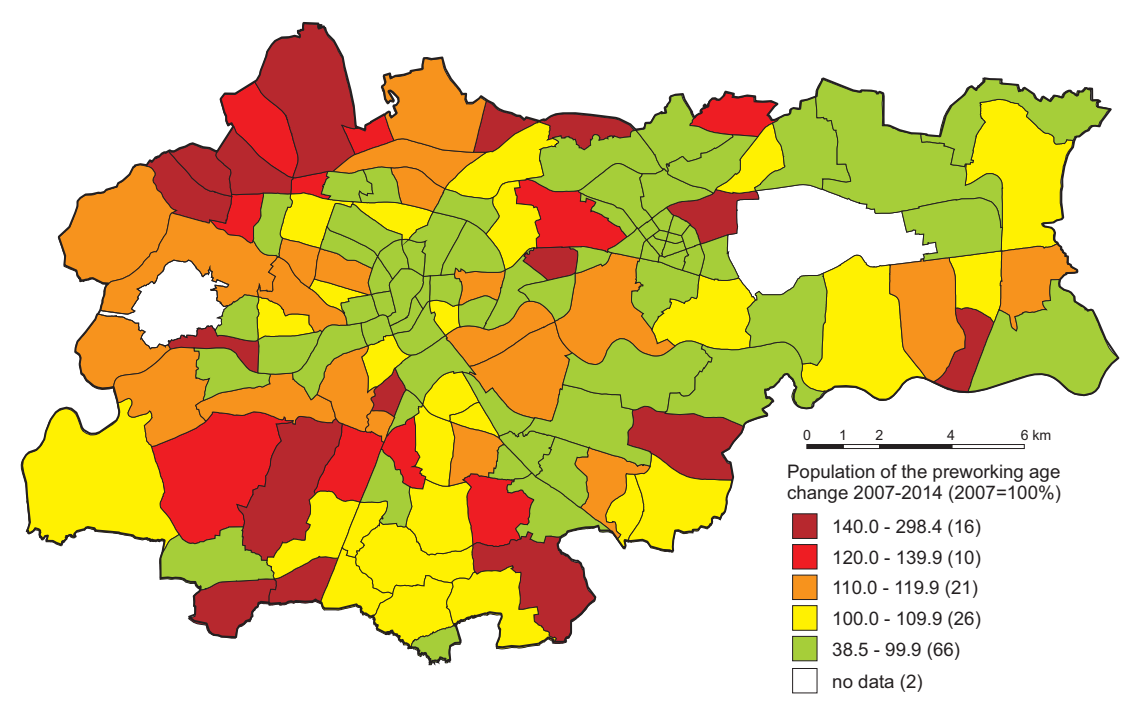

Figure 4. Changes in the number of the pre-working population (aged under 18) in the years 2007-2014 
tion (18-44) was similar to the changes in the size of the pre-working population, however in the post-industrial areas near the central part of the city, the growth rate was even higher (Fig. 5). For example, in the above-mentioned district of Zabłocie the growth rate was $60 \%$. In 15 urban wards, the growth rate of people in this age category was the highest among all the economic age groups analysed. The largest decrease in the size of the young productive population was noted in the centre (e.g. $24 \%$ in the Stare Miasto or Old Town district - no. 1, and 30\% in the Stradom district - no. 6, connecting the Old Town with Kazimierz - no. 7).

The increase in the size of the non-mobile productive population took place in 66 urban wards which also included peripheral districts and housing estates located near industrial and service areas (stretching from the centre to Nowa Huta; Fig. 6). The largest increase recorded in this category of population was in 28 wards, mainly in Nowa Huta (except for its central area). Among the post-working age population, the greatest increase was recorded in the former housing estates constructed of large prefabricated blocks, both in the northern and southern parts of the city (Fig. 7). In general, this age group noted the largest number of wards with an increase in population size ( 80 which accounted for $57 \%$ of the total number and in 41 housing estates, the growth rate was the highest among all the population categories analysed. This confirms the progressive ageing process of the population. However, the central districts noted a decline, both in the older post-production group as well as the retirement-age population (Fig. 7).

To include the level of demographic ageing in both periods studied, the ageing index was used to determine the number of people aged 65 and over per 100 people aged under 15. Both figures show high index values, both in the downtown area and in the central part of Nowa Huta, whereas low values are noted in the outskirts of the city (Figs. 8 and 9). While comparing the data from 2007 and 2014, we can observe an increase in age in the large-block housing estates (e.g. wards 80-82). It should be emphasised that in the year 2007 the share of older people (over 65 years of age) was twice the share of children under the age of 15 in 24 urban wards, while in the year 2014 - in 25 urban wards, and in the period from 2007 to 2014 there was an increase in the value of this index in 80 districts.

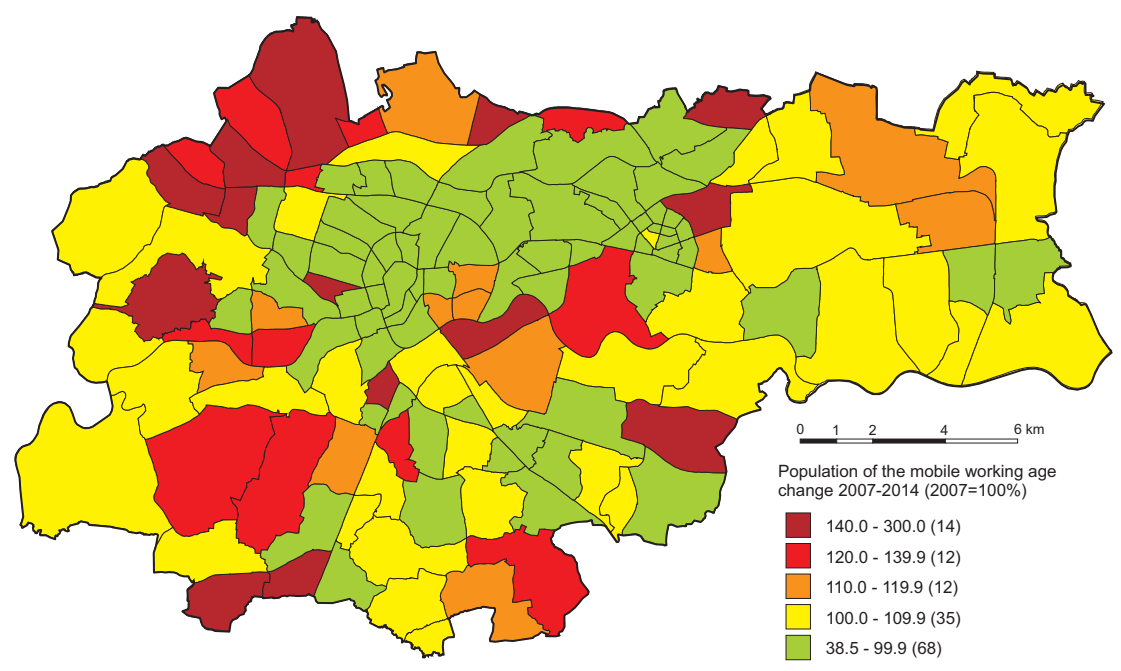

Figure 5. Changes in the number of mobile working population (aged 18-44) in the years 2007-2014 


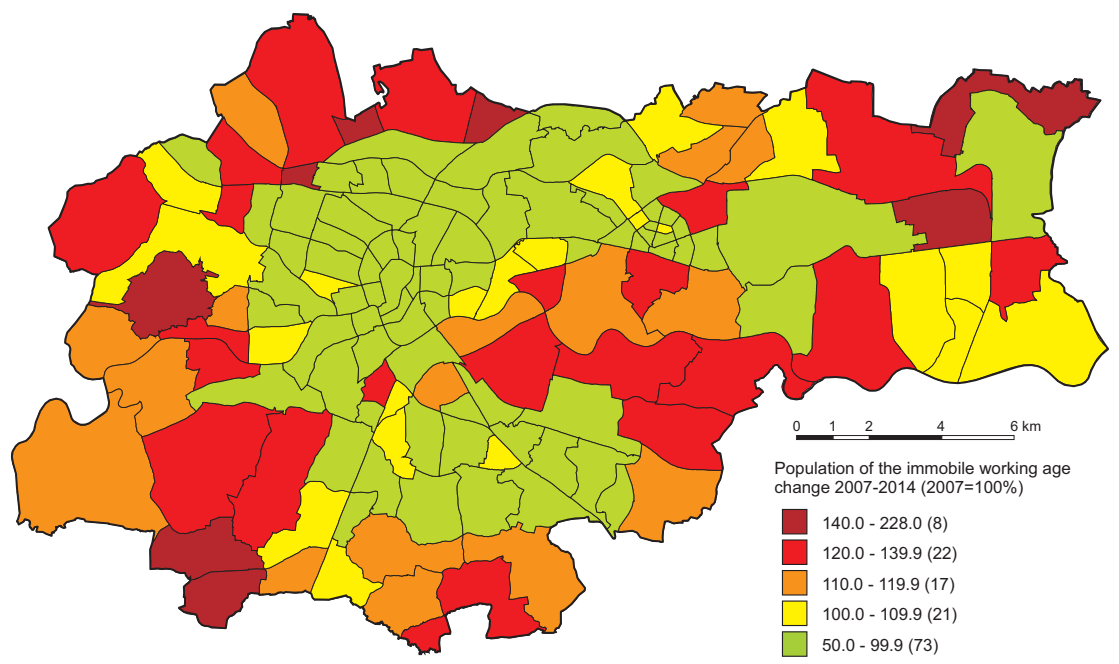

Figure 6. Changes in the number of the immobile working population (aged 45-59 females and 45-64 males) in the years 2007-2014

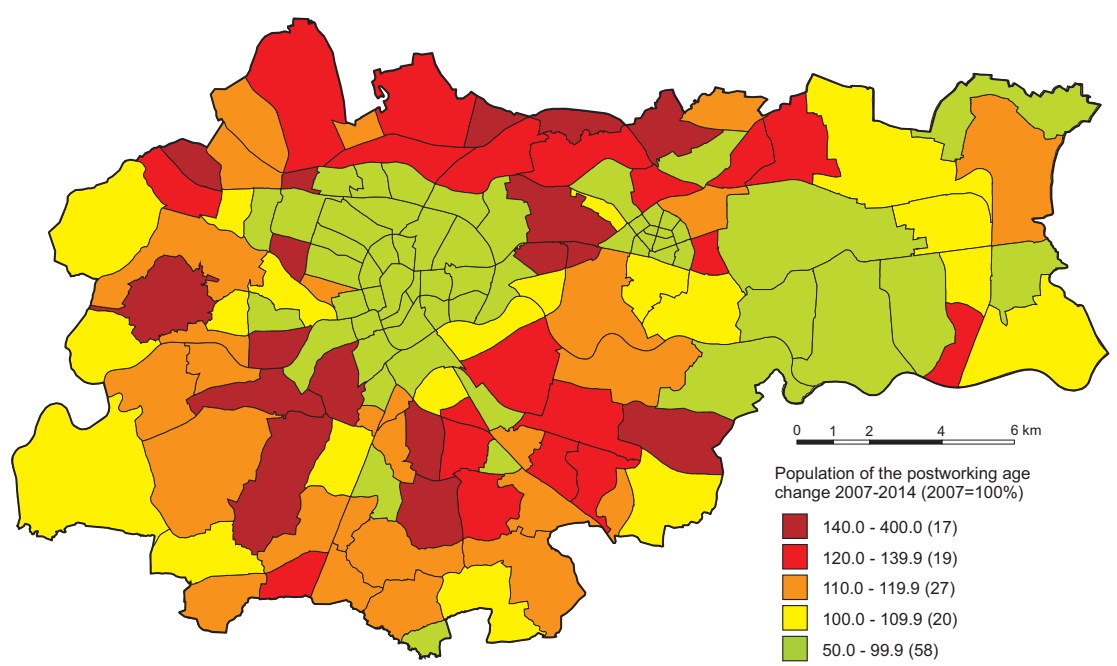

Figure 7. Changes in the number of post-working population (aged 60 years and over females and 65 and over males) in the years 2007-2014

In this case, the dynamics of the population ageing process was determined on the basis of two indicators based on changes in the shares of the selected age groups of the population. The demographic ageing index $\left(\mathrm{W}_{\mathrm{SD}}\right)$ is calculated on the basis of the percentage point difference between the share of the young and the elderly population (Długosz 1998). The higher the value of this indicator, the more dynamic that society's ageing process. On the other hand, negative 


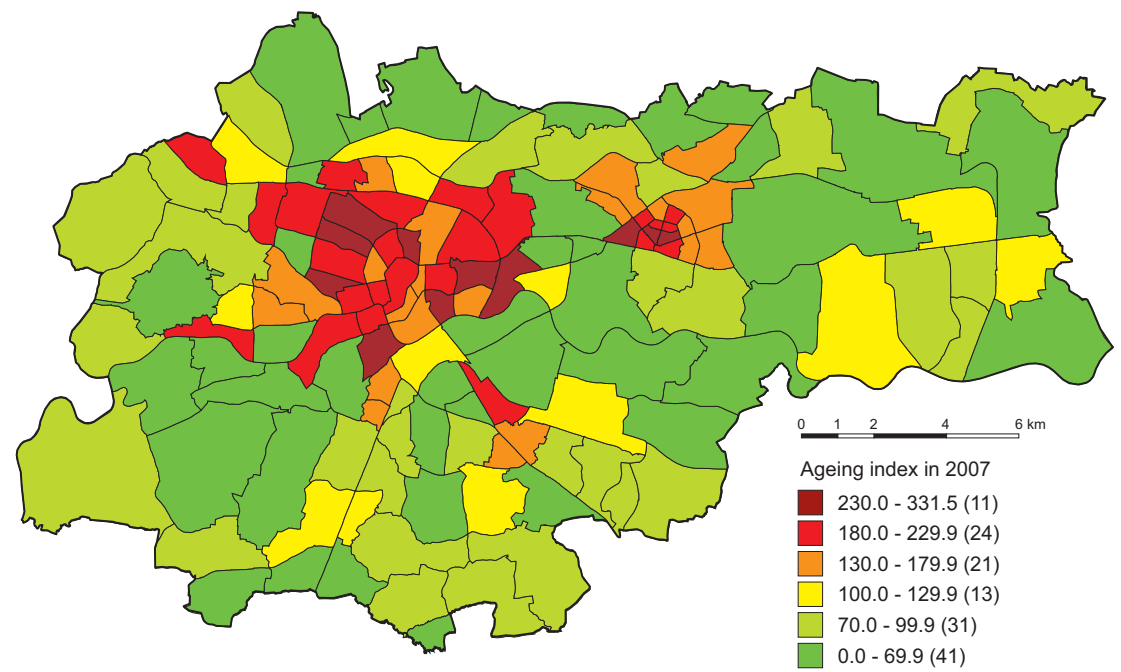

Figure 8. Ageing index in 2007 (the number of the population aged 65 and over per 100 population aged under 15)

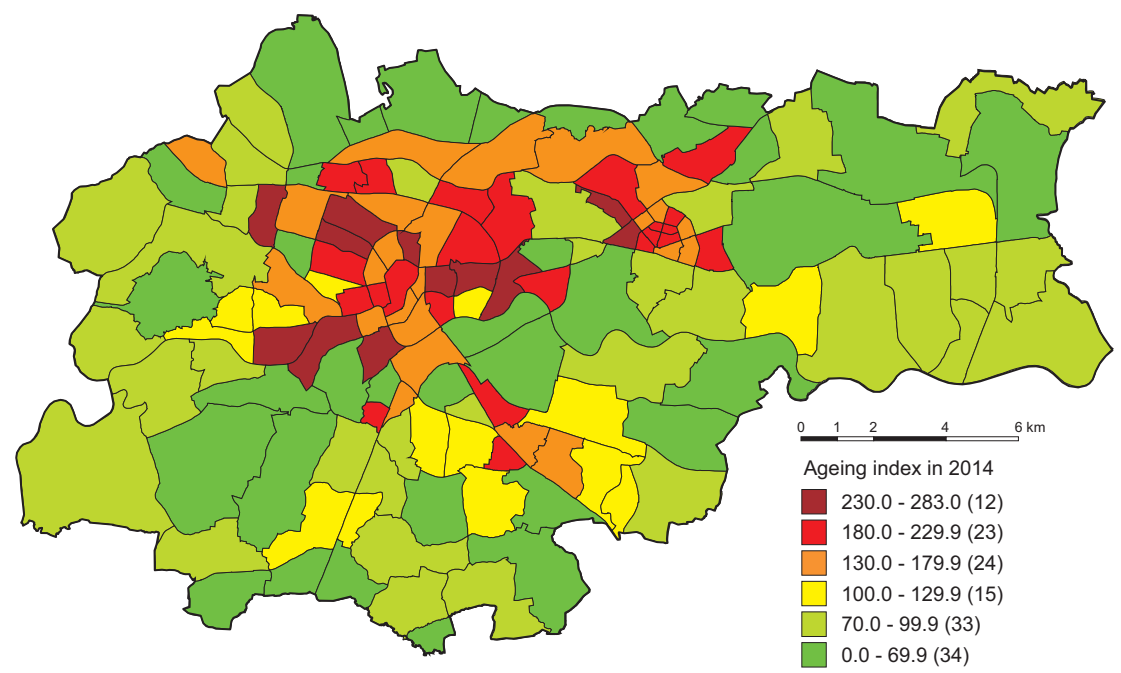

Figure 9. Ageing index in 2014 (the population aged 65 and over per 100 population aged under 15)

values of the $W_{S D}$ index confirm rejuvenation of the population ${ }^{1}$.

\footnotetext{
${ }^{1} W_{S D}=\left[U_{(0-14) t}-U_{(0-14) t+n}\right]+\left[U_{(\geq 65) t+n}-U_{(\geq 65) t}\right]$

$W_{S D}$ - dynamic ageing index;

$\mathrm{P}(0-14) \mathrm{t}$ - share of population aged $0-14$ at the beginning of the period studied;
}

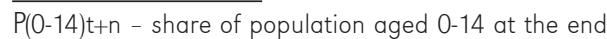
of the period studied;

$P(>65) t+n$ - share of population aged 65 and more at the end of the period studied;

$P(>65) t$ - share of population aged 65 and more at the beginning of the period studied. 
In Kraków, in the period from 2007 to 2014 , positive values of the $W_{S D}$ index were recorded in 82 urban wards (58\% of the total number) indicating the progressive ageing of the inhabitants, based on changes in the share of the young and old age groups of the population. The cartogram (Fig. 10) shows that Śródmieście and also the oldest part of Nowa Huta are beginning to rejuvenate despite the fact that the population size is falling. Thus, generation change is observed in these areas. The population of the prefabricated housing estates (southern and northern parts of Kraków) are getting older whereas the outskirts of the city - where new housing development starts - are beginning to rejuvenate.

The economic ageing index $\mathrm{W}_{S E}{ }^{2}$ (Kurek 2008) is based on the percentage point changes in four age groups according to economic criteria.

The way this indicator is calculated is based on the assumption that an increase in the share of the pre-production and mobile production population leads to the rejuvenation of society, while an increase in the percentage of people of non-mobile production age and post-production age results in the process of ageing of the population. According to $W_{S E}$, population ageing was observed in 72 of the wards examined (51\% of the total number). In comparison with the $W_{S D}$ index based on only two age groups of the population, it is observed that in the event of four age groups of the population being considered, including the two groups representing working resources, the phenomenon of rejuvenation affects more areas in the centre (Fig. 11), including the ring around the

\footnotetext{
${ }^{2} W_{S E}=\left[P_{(m) t}-P_{(m) t+n}\right]+\left[P_{(p m) t}-P_{(p m) t+n}\right]+\left[P_{(\rho) t+n}-P_{(\rho) t)}\right]$ $+\left[P_{(s) t+n}-P_{(s) t}\right]$

$W_{S E}^{(s) t+n}$ economic ageing index

$P_{(m)}^{S E}$ - share of the pre-working age population at the beginning $(t)$ and at the end $(t+n)$ of the study period $\mathrm{P}_{(\mathrm{pm})}$ - share of mobile working age population at the beginning $(\mathrm{t})$ and at the end $(\mathrm{t}+\mathrm{n})$ of the study period $P_{(p s)}$ - share of immobile working age population at the beginning $(t)$ and at the end $(t+n)$ of the study period $P_{(s)}$ - share of post-working age population at the beginning $(t)$ and at the end $(t+n)$ of the study period
}

Old Town (e.g. wards 2-5, Kazimierz - ward 7) or Stare Podgórze (ward 89) and Zabłocie (ward 90).

\section{Functional zones}

The next stage of the analysis involved an examination of the population chages in Kraków, divided into the functional zones which were distinguished by Zborowski in 1998 (Zborowski 2005: 142). The author defined eight major functional zones within the city. It was noted that within each zone there was both functional similarity and similar development. The application of this division allows one to observe more general patterns regarding the population changes (Fig. 12).

The largest depopulation occurred within the old medieval city centre (Centre I) which lost nearly $17 \%$ of its population in the years from 2007 to 2014 (Tab. 1). The depopulation process of this area has been taking place uninterruptedly since the 1950s and is associated with functional changes consisting of an increased importance of tourism, commerce and catering. An insignificantly slower depopulation process was recorded in the second central zone (Centre II) surrounding the medieval old town. In the next two zones surrounding the old centre (fringes of the centre: Śródmieście) and the oldest part of the Nowa Huta district, there was also a general decline in population size. It must be noted that in the case of the first zone, an insignificant increase in the population size aged 0-14 was recorded in the period examined, confirming an emerging reurbanisation process (Tab. 1).

Interesting changes have also occurred in the urban zone including large housing estates which houses almost $55 \%$ of the city's population. In the period examined there was an insignificant decrease in population size (1.7\%) and - at the same time - an over 30\% increase in the post-production population size and an only $3.6 \%$ increase in the number of children up to 15 years of age. This confirms that that the fall in the population size 


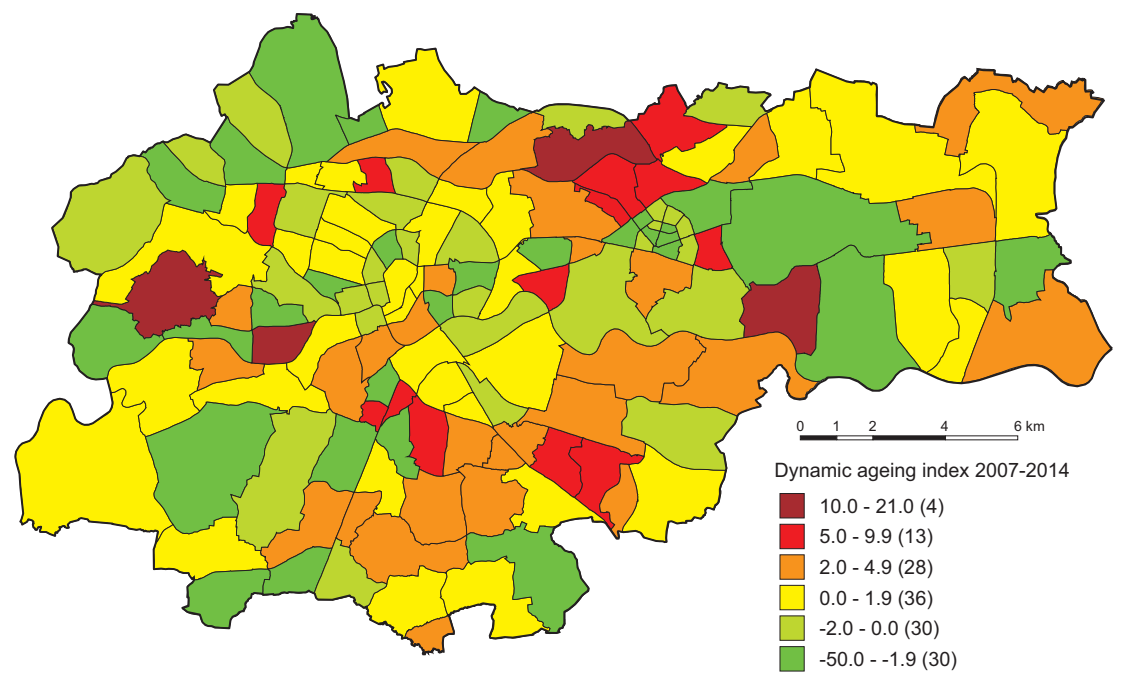

Figure 10. Dynamic ageing index in the years 2007-2014

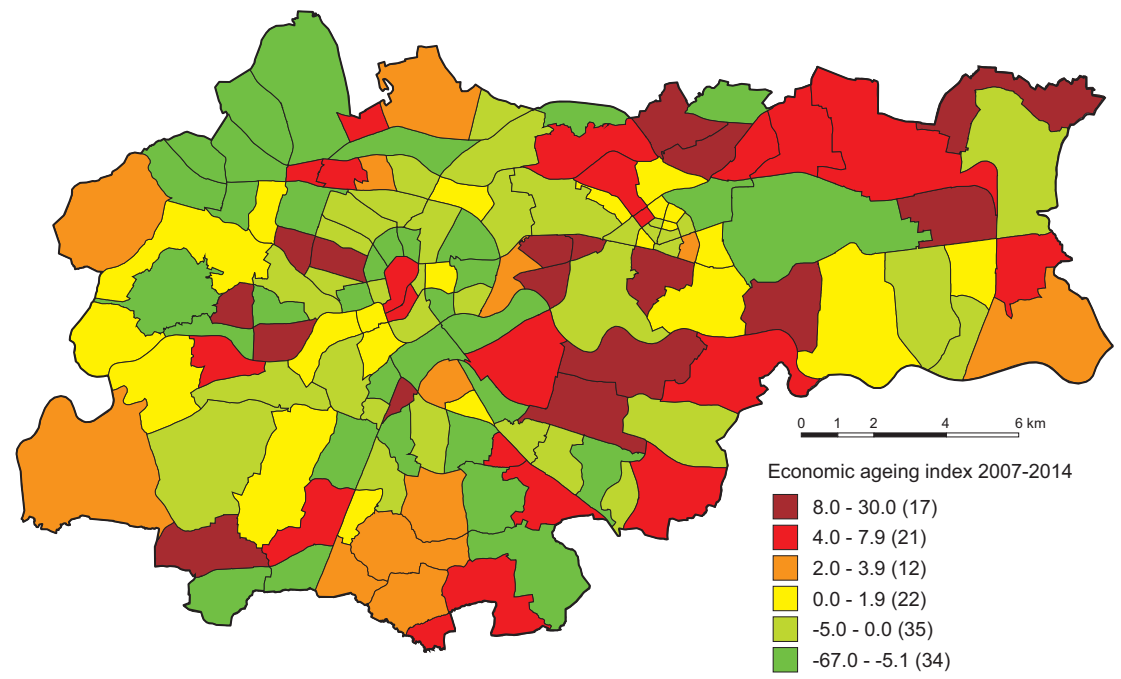

Figure 11. Economic ageing index in the years 2007-2014

in this zone is attributable to people of production age who move to other parts of the city or to the suburban areas. The outflow of people in this age group is 'neutralised' by the influx of people of post-production age. In the period examined, their number increased by nearly 18.7 thousand, which indicates a significant migration inflow of this population to the zone examined (Tab. 1).
For the three most external functional zones of the city, there was a distinct increase in population size related to deconcentration processes in the population and internal suburbanisation (Więcław-Michniewska 2006). The fastest population growth was recorded in both suburbanisation zones (Suburban I and II) and - interestingly - in both of them the rate of population growth in the pre-pro- 


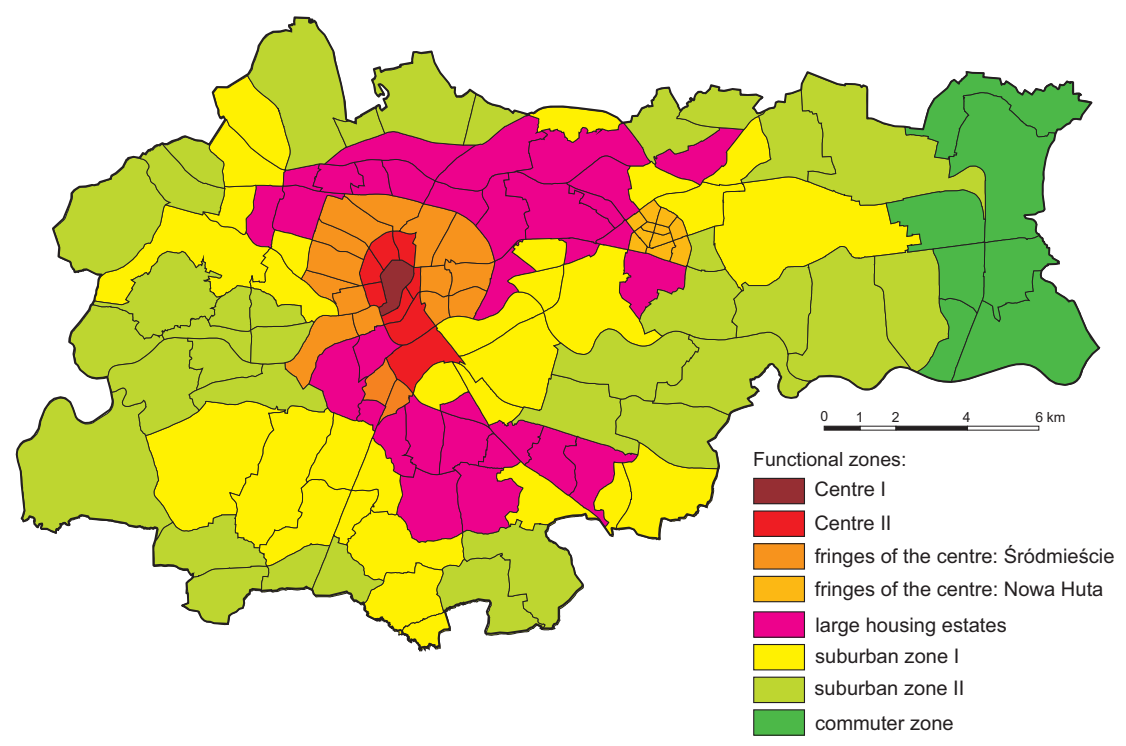

Figure 12. Typology of Kraków according to functional zones

Source: authors' analysis based on Zborowski's classification (Zborowski 2005: 142).

duction and post-production age groups was significantly higher than the average growth rates (Tab. 1).
The indicators of the population ageing dynamics in the individual functional zones of Cracow presented in Table 2 confirm the

Table 1. Population changes according to the functional zones of Kraków: 2007 and 2014

\begin{tabular}{|c|c|c|c|c|c|c|c|c|c|}
\hline \multirow{3}{*}{ Functional zones } & \multicolumn{6}{|c|}{ Population } & \multirow{2}{*}{\multicolumn{3}{|c|}{$\begin{array}{l}\text { Population change } \\
2007=100 \%\end{array}$}} \\
\hline & \multicolumn{3}{|c|}{2007} & \multicolumn{3}{|c|}{2014} & & & \\
\hline & Total & $0-14$ & $65+$ & Total & $0-14$ & $65+$ & Total & $0-14$ & $65+$ \\
\hline Centre I & 4,725 & 428 & 891 & 3,929 & 363 & 811 & 83.2 & 84.8 & 91.0 \\
\hline Centre II & 54,416 & 6,034 & 9,483 & 47,748 & 5,284 & 8,594 & 87.7 & 87.6 & 90.6 \\
\hline $\begin{array}{l}\text { Fringes of the centre: } \\
\text { Śródmieście }\end{array}$ & 87,556 & 7,926 & 18,189 & 79,092 & 8,097 & 17,303 & 90.3 & 102.2 & 95.1 \\
\hline $\begin{array}{l}\text { Fringes of the centre: } \\
\text { Nowa Huta }\end{array}$ & 40,941 & 4,663 & 9,200 & 37,680 & 4,366 & 7,703 & 92.0 & 93.6 & 83.7 \\
\hline Large housing estates & 409,304 & 51,566 & 62,058 & 402,156 & 53,422 & 80,728 & 98.3 & 103.6 & 130.1 \\
\hline Suburban zone I & 96,971 & 15,853 & 9,896 & 112,577 & 20,671 & 12,901 & 116.1 & 130.4 & 130.4 \\
\hline Suburban zone II & 46,823 & 8,088 & 4,772 & 56,772 & 10,643 & 5,980 & 121.2 & 131.6 & 125.3 \\
\hline Commuter zone & 4,643 & 831 & 585 & 4,956 & 845 & 686 & 106.7 & 101.7 & 117.3 \\
\hline Total & 745,379 & 95,389 & 115,074 & 744,910 & 103,691 & 134,706 & 99.9 & 108.7 & 117.1 \\
\hline
\end{tabular}

Source: authors' analysis based on data from the Municipality of Kraków, City Government Office (The same applies to Tabs. 2 and 3 ). 
Table 2. Changes in the ageing indicators by the functional areas of Kraków: 2007 and 2014

\begin{tabular}{|l|c|c|c|c|}
\hline \multirow{2}{*}{\multicolumn{1}{|c|}{ Functional zones }} & \multicolumn{2}{|c|}{ Index of demographic aging } & \multirow{2}{*}{ Wsd } & \multirow{2}{*}{ Wse } \\
\cline { 2 - 3 } & Isd. 2007 & Isd. 2014 & & \\
\hline Centre I & 208.2 & 223.4 & 1.60 & 7.53 \\
Centre II & 157.2 & 162.6 & 0.59 & -3.79 \\
Fringes of the centre: Śródmieście & 229.5 & 213.7 & -0.08 & -0.55 \\
Fringes of the centre: Nowa Huta & 197.3 & 176.4 & -2.23 & -0.15 \\
Large housing estates & 120.3 & 151.1 & 4.23 & -0.04 \\
Suburban zone I & 62.4 & 62.4 & -0.76 & -0.13 \\
Suburban zone II & 59.0 & 56.2 & -1.13 & -1.72 \\
Commuter zone & 70.4 & 81.2 & 2.09 & 2.92 \\
Total & 120.6 & 129.9 & 1.52 & -1.32 \\
\hline
\end{tabular}

ageing process in Kraków city centre, however, in the Centre II area, the economic ageing index $W_{S E}$ reveals the rejuvenation of this area despite the fact that the $W_{S D}$ indicator demonstrates something else. The difference is that there are favourable changes in the structure of the workforce resources. The share of younger people of working age increases and the percentage of the older people of working age in the population decreases (Tab. 3), which is not included in the $W_{S D}$ index based only on the share of children and retired. The rejuvenation process is also observed in the immediate vicinity of the centre and in the old part of Nowa Huta. Housing estates consisting of blocks of flats demonstrate a quite intensive ageing process according to the $W_{S D}$ index (mainly through

Table 3. Changes in the population structure by economic age group in the functional areas of Kraków in 2007 and 2014

\begin{tabular}{|c|c|c|c|c|c|c|c|c|}
\hline \multirow[b]{2}{*}{ Functional zones } & \multicolumn{4}{|c|}{2007} & \multicolumn{4}{|c|}{2014} \\
\hline & 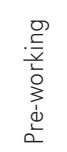 & 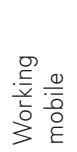 & 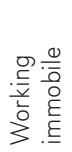 & 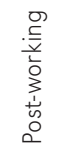 & 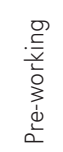 & 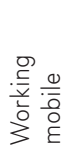 & 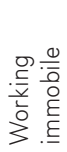 & 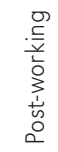 \\
\hline Centre I & 11.8 & 39.6 & 24.2 & 24.4 & 11.5 & 36.1 & 27.5 & 24,9 \\
\hline Centre II & 14.3 & 37.4 & 25.9 & 22.4 & 13.5 & 40.1 & 24.1 & 22.3 \\
\hline Fringes of the centre: Śródmieście & 11.8 & 40.5 & 22.5 & 25.2 & 12.6 & 39.9 & 21.5 & 26.0 \\
\hline Fringes of the centre: Nowa Huta & 14.9 & 35.5 & 24.3 & 25.3 & 14.2 & 36.3 & 24.9 & 24.6 \\
\hline Large housing estates & 15.3 & 39.1 & 24.4 & 21.3 & 15.7 & 38.6 & 21.1 & 24.5 \\
\hline Suburban zone I & 19.6 & 45.5 & 20.8 & 14.0 & 21.1 & 44.1 & 20.3 & 14.5 \\
\hline Suburban zone II & 21.4 & 42.5 & 22.3 & 13.9 & 21.7 & 43.0 & 21.7 & 13.6 \\
\hline Commuter zone & 22.3 & 40.1 & 20.9 & 16.7 & 20.7 & 40.3 & 22.2 & 16.8 \\
\hline Total & 15.7 & 40.0 & 23.7 & 20.6 & 16.4 & 39.9 & 21.5 & 22.1 \\
\hline
\end{tabular}


an increased share of the post-production population) while changes in the economic age groups suggest a different tendency. The decline in the size of the working-age population results from migration to the suburban area, yet the loss of the young population of working age is compensated by those arriving in Cracow or staying in the city after graduation from universities. Housing estates consisting of blocks of flats possess good transport link accessibility to the centre and they offer attractive prices for flats which are willingly bought or rented by young, less affluent people. Furthermore, the phenomenon of rejuvenation of the population also occurs in the suburbanisation zones as well.

\section{Discussion and conclusions}

Can the demographic changes presented here from the spatial layout perspective confirm the progress of the process of reurbanisation in the central part of Kraków? Despite the fact that we are observing real population decline in the downtown and the oldest part of Nowa Huta, specific housing estates located in the centres of both parts of the city have noted rejuvenation of the demographic structures, particularly among young people of production age and pre-production age.

These transformations may indicate the beginnings of the reurbanisation phase and the associated processes of regeneration and gentrification of specific urban wards, in particular post-industrial districts located in close proximity to the centre (Zabłocie, Grzegórzki, Stare Podgórze). The regeneration programmes carried out increase the attractiveness of these locations and contribute to the development of cultural values while increasing the prestige of living in the renovated district (Gadecki 2013).

The reurbanisation process is facilitated by the second demographic transition - the influx of young people of mobile age, a diversity of households and a low level of fertility. The process of regenerating the historic centre of Kraków, as well as those of other cities of Central and Eastern Europe or West- ern Europe, constitutes a factor supporting reurbanisation processes. They include the transformation of post-industrial zones, the creation of new cultural institutions and shopping centres, or the construction of modern housing estates. The change in the housing preferences of young households plays an important role. Young people who postpone starting families and having children benefit from living near city centres, not only because of their proximity to the workplace, but also because they have easy access to a range of cultural facilities, entertainment venues and a variety of services.

The process of urban renewal also applies to the former working-class district - Nowa Huta. Purchasers recognise the value of the older settlements with trusted construction technology (brick buildings with good thermal insulation dominate among the old ones) as well as a well-prepared and completed urban layout. As compared to modern housing projects, the former Nowa Huta housing estates offer a lot of greenery, good parking facilities and - above all - appropriate infrastructure: communications, education and health. The quality of communication with the city centre constitutes a vital element (Gadecki 2013). The sense of identity of the inhabitants of Nowa Huta and the presence of its remaining cultural heritage as a representative example of socialist realism is of great importance. Furthermore, Nowa Huta functions as a supra-local cultural centre, home to numerous artistic and cultural backgrounds. The Local Regeneration Programme of 'old' Nowa Huta (rewitalizacja. Krakow.pl.pl/zalacznik/169183) includes, among other projects, the development of the green areas of 'Nowa Huta Meadows' for recreation and the establishment of a science and technology park. The above-mentioned activities may contribute to an increase in the employment rate in the local population.

The demographic processes taking place in Kraków and its functional area in relation to reurbanisation processes are similar to the development of other cities in both Poland and in the Central and Eastern Euro- 
pean countries as well as in Western Europe (Haase A. 2008; Couch et al. 2009; Haase A. et al. 2010, 2012a, 2012b; Kabisch \& Haase D. 2011; Śleszyński 2013). Despite the fact that signs of reurbanisation in western cities were noticed much earlier, with the spread of the second demographic transition many post-socialist cities are now undergoing the reurbanisation phase. Kraków is also considered to be a city subject to the reurbanisation process and the urban transformations related to the presence of two central areas - the one connected to the Old Town, and another, to the centre of the former industrial district, i.e, Nowa Huta - are interesting. The research results obtained from this analysis may contribute to the literature concerning

\section{References}

Beauregard R.A., 2009: Urban population loss in historical perspective: United States, 1820-2000. Environment and Planning A, vol. 41 , no. 3, pp. 514-528.

Bouzarovski S., Haase A., Hall R., Steinführer A., KaBISCH S., Ogden P.E., 2010. Household structure, migration trends, and residential preferences in inner-city León, Spain: Unpacking the demographies of reurbanization. Urban Geography, vol. 31, no. 2, pp. 211-235.

Brzosko-Sermak A., PŁaziak M., Trzepacz P., 2017. Przemiany funkcji handlowych i usługowych centrum dzielnicy mieszkaniowej na przykładzie Krakowa-Nowej Huty. Prace Komisji Geografii Przemysłu Polskiego Towarzystwa Geograficznego, vol. 31, no. 2, pp. 95-110.

Buzar S., Ogden P., Hall R., 2005. Households matter: The quiet demography of urban transformation. Progress in Human Geography, vol. 29, no. 4, pp. 413-436.

Buzar S., Hall R., Ogden P.E., 2007a. Beyond gentrification: The demographic reurbanization of Bologna. Environment and Planning A, vol. 39, no. 1, pp. 64-85.

Buzar S., Ogden P., Hall R., Haase A., Kabisch S., SteINFüHRER A., 2007b. Splintering urban populations: Emergent landscapes of reurbanisation in four European cities. Urban Studies, vol. 44, no. 4, pp. 651-677. urban development so that the reurbanisation processes can take place separately in two different inner-city areas taking into consideration their historical conditions.

It should be assumed that in the shorter and longer term, Kraków - due to its cultural, employment and educational attractiveness - will attract young people who will increasingly choose those regenerated areas located nearest to the city centre.

\section{Acknowledgements}

The study was supported by National Science Centre, Poland as a research project no 2017/25/B/HS4/02261.

Champion A.G., 2001. A changing demographic regime and evolving polycentric urban regions: Consequences for the size, composition and distribution of city populations. Urban Studies vol. 38, no. 4, pp. 657-677.

CheshiRe P., 1995. A new phase of urban development in Western Europe? The evidence for the 1980s. Urban Studies vol. 32, no. 7, pp. 1045-1063.

Couch C., Fowles S., Karecha J., 2009. Reurbanization and housing markets in the central and inner areas of Liverpool. Planning Practice \& Research vol. 24, no. 3, pp. 321-341.

DŁugosz Z., 1998. Próba określenia zmian starości demograficznej Polski w ujęciu przestrzennym. Wiadomości Statystyczne, vol. 3, pp. 15-25.

Fol S., Cunningham-Sabot E., 2010. "Déclin urbain» et Shrinking Cities: une évaluation critique des approches de la décroissance urbaine. Annales de géographie, vol. 674, no. 4, pp. 359-383.

FrIEDRICHS J., 1993. A theory of urban decline: Economy, demography and political elites. Urban Studies, vol. 30, no. 6, pp. 907-917.

GĄDECKI J., 2013. Odkrywajqc miasto idealne? Marginalna gentryfikacja starej części dzielnicy Nowa Huta. Studia Regionalne i Lokalne, vol. 4, no. 54, pp. 64-81. 
GLASS R., 1964. London: aspects of change. Centre for Urban Studies report, no 3, London: MacGibbon \& Kee.

Glatter J., Siedhoff M., 2008. Reurbanisation: Inflationary use of an insufficiently defined term? Comments of the definition of a key concept of urban geography, with selected findings for the city of Dresden. Die Erde, vol. 139, no. 4, pp. 289-308.

GRABKOWSKA M., 2012. Regeneration of the postsocialist inner city. Social change and bottomup transformations in Gdańsk. Gdańsk: Czysty Warsztat.

Hall P., HaY D., 1980. Growth centres in the European urban system. London: Heinemann Educational.

HaAse A., 2008. Reurbanisation - An analysis of the interaction between urban and Demographic change: A comparison between European cities. Die Erde, vol. 139, no. 4, pp. 309-332.

HaAse A., Kabisch S., Steinführer A., BouZarovski S., Hall R., Ogden P. E., 2010. Emergent spaces of reurbanisation: Exploring the demographic dimension of inner-city residential change in a European setting. Population, Space and Place, vol. 16, no. 5, pp. 443-463.

HaAse A., Grossmann K., Steinführer A., 2012a. Transitory urbanites: New actors of residential change in Polish and Czech inner cities. Cities, vol. 29, no. 5, pp. 318-326.

HaAse A., Herfert G., Kabisch S., Steinführer A., 2012b. Reurbanizing Leipzig (Germany): Context conditions and residential actors (2000-2007). European Planning Studies, vol. 20, no. 7, pp. 1173-1196.

HaAse A., Wolff M., ŠpačKová P., RadZIMski A., 2017. Reurbanisation in postsocialist Europe - A comparative view of Eastern Germany, Poland, and the Czech Republic. Comparative Population Studies - Zeitschrift für Bevölkerungswissenschaft, vol. 42, pp. 353-390.

HaAse D., HaAse A., Kabisch S., Bischoff P., 2008. Guidelines for the "Perfect Inner City". Discussing the appropriateness of monitoring approaches for reurbanization. European Planning Studies, vol. 16, no. 8, pp. 1075-1100.

Hamnett C., 2003. Gentrification and the middleclass Remaking of Inner London, 1961-2001. Urban Studies, vol. 40, no. 12, pp. 2401-2426.
Herfert G., 2002. Disurbanisierung und Reurbanisierung. Polarisierte Raumentwicklung in der ostdeutschen Schrumpfungslandschaft. Raumforschung und Raumordnung, vol. 60, no. 5-6, pp. 334-344.

Kabisch S., Steinführer A., HaAse A., Grossmann A., Peter A., MaAs A., 2008. Demographic change and its impact on housing. Final report for EUROCITIES. Leipzig-Brussels: European Commission.

Kabisch N., HaAse D., 2011. Diversifying European agglomerations: Evidence of urban population trends for the 21st Century. Population, Space and Place, vol. 17, no. 3, pp. 236-253.

Kabisch N., HaAse D., HaAse A., 2012. Urban population development in Europe, 1991-2008: The Examples of Poland and the UK. International Journal of Urban and Regional Research, vol. 36, no. 6, pp. 1326-1348.

Kramer C., Pfaffenbach C., 2016. Should I stay or should I go? Housing preferences upon retirement in Germany. Journal of Housing and the Built Environment, vol. 31, no. 2, pp. 239-256.

KUHN G., 2007. Reurbanisierung, Renaissance der Stadte und Stadtwohnen. Informationen zur modernen Stadtgeschichte, vol. 2, pp. 121-130.

KUREK S., 2008. Typologia starzenia się ludności Polski w ujęciu przestrzennym. Kraków: Wydawnictwo Naukowe Akademii Pedagogicznej.

Kurek S., Wójtowicz M., Gatka J., 2017. Does suburbanisation contribute to the rejuvenation of a metropolitan area? Changes in the age structure of the Kraków metropolitan area in Poland in the light of recent suburbanization. Geographia Polonica, vol. 90, no. 2, pp. 59-70.

Lesthaeghe R., 2010. The unfolding story of the second demographic transition. Population and Development Review, vol. 36, no. 2, pp. 211-251.

Motak M., 2007. Przemiany urbanistyki, architektury i krajobrazu kulturowego Krakowa w latach 1989-2007. Zarys problematyki. Wiadomości Konserwatorskie, vol. 21, pp. 28-33.

Mydel R., 1994. Rozwój urbanistyczny miasta Krakowa po drugiej wojnie światowej. Kraków: Wydawnictwo Secesja.

Mydel R., 1996. Terytorialny wzrost i ewolucja struktury przestrzennej miasta Krakowa w okresie 1946-1990. Folia Geographica, Series Geographica-Oeconomica, vol. 27-28, pp. 279-296. 
Ogden P.E., Hall R., 2000. Households, reurbanisation and the rise of living alone in the principal French cities. Urban Studies, vol. 37, no. 2, pp. 367-390.

OuŘEdní̌̌ek M., ŠIMON M., KopeČNÁ M., 2015. The reurbanisation concept and its utility for contemporary research on post-socialist cities: The case of the Czech Republic. Moravian Geographical Reports, vol. 23, no. 4, pp. 26-35.

PŁaZIAK M., 2014. Przemiany funkcji handlowousługowych $w$ mieście postsocjalistycznym na przykładzie Nowej Huty [in:] E. Kaczmarska, P. Raźniak (eds.), Społeczno-ekonomiczne i przestrzenne przemiany struktur regionalnych, pp. 85-98. Kraków: Oficyna Wydawnicza AFM.

Steinführer A., HaAse A., 2007. Demographic change as future challenge for cities in East Central Europe. Geografiska Annaler: Series B, Human Geography, vol. 89, no. 2, pp. 183-195.

ŚLESZYŃSKI P., 2013. Demographic changes in the functional urban areas in Poland, 2000-2010. Geographia Polonica, vol. 86, no. 2, pp. 169-170.

Turok I., Mykhnenko V., 2007. The trajectories of European Cities, 1960-2005. Cities, vol. 24, no. 3, pp. 165-182.

USK, 2003. Gospodarstwa domowe i rodziny. Województwo małopolskie, 2003. Narodowy Spis Powszechny Ludności i Mieszkań. Powszechny Spis Rolny, Kraków: Urząd Statystyczny w Krakowie.

USK, 2014. Gospodarstwa domowe i rodziny w województwie małopolskim. Charakterystyka demograficzna. Narodowy Spis Powszechny Ludności i Mieszkań 2011, Kraków: Urząd Statystyczny w Krakowie. van den Berg L., Drewett R., KlaAsen L., Rossi A., ViJVerberG H., 1982. Urban Europe: A study of growth and decline. Oxford: Pergamon Press.

VAN DE KAA D., 1987. Europe's second demographic transition. Population Bulletin, vol. 42, pp. 1-57.

WięCtaW-MichnieWSKa J., 2006. Krakowskie suburbia i ich społeczność. Kraków: Instytut Geografii i Gospodarki Przestrzennej Uniwersytetu Jagiellońskiego.

Wójtowicz M., Kurek S., GaŁKa J., 2014. Suburbanization in the Krakow Metropolitan Region (KMR) in the years 1995-2010 [in:] M. Czerny, G. Hoyos Castillo (eds.), Suburbanization versus peripheral sustainability of rural-urban areas fringes, Hauppauge, New York: Nova Science Publishers, pp. 123-146.

ZвOROWSkı A., 2005. Przemiany struktury społecznoprzestrzennej regionu miejskiego $w$ okresie realnego socjalizmu i transformacji ustrojowej (na przykładzie Krakowa). Kraków: Instytut Geografii i Gospodarki Przestrzennej Uniwersytetu Jagiellońskiego.

ZBOROWSKI A., 2009.Zmiany zasięgu oddziaływania miast $w$ Polsce $w$ okresie transformacji systemowej, na przykładzie dojazdów do pracy [in:] Z. Górka, A. Zborowski (eds.), Człowiek i rolnictwo, pp. 249-263. Kraków: Instytut Geografii i Gospodarki Przestrzennej Uniwersytetu Jagiellońskiego.

Zborowski A., Soja M., 2009. Demograficzne uwarunkowania rewitalizacji $w$ miastach polskich [in:] A. Zborowski (ed.), Demograficzne i społeczne uwarunkowania rewitalizacji miast w Polsce, pp. 16-60. Kraków: Instytut Rozwoju Miast. 
Annex. Administrative division of Kraków (Fig. 3)

\begin{tabular}{|c|c|c|}
\hline $\begin{array}{c}\text { Registration } \\
\text { units }\end{array}$ & Districts & Urban enumeration districts - wards \\
\hline \multirow{3}{*}{ Śródmieście } & Stare Miasto & $\begin{array}{l}1 \text { - Stare Miasto, } 2 \text { - Kleparz, } 3 \text { - Piasek Pn., } 4 \text { - Piasek Pd., } 5 \text { - Nowy Świat, } \\
6 \text { - Stradom, } 7 \text { - Kazimierz, } 8 \text { - Wesoła Zachód } 9 \text { - Warszawskie }\end{array}$ \\
\hline & Grzegórzki & $\begin{array}{l}\text { 10Wesoła Wsch., } 11 \text { - Grzegórzki Zach., } 12 \text { - Grzegórzki Wsch., } 13 \text { - Grzegórzki } \\
\text { Pn., } 14 \text { - Osiedle Oficerskie, } 15 \text { - Dąbie }\end{array}$ \\
\hline & Prq̨dnik Czerwony & 16 - Olsza, 17 - Rakowice, 18 - Pradnik Czerwony \\
\hline \multirow{4}{*}{ Krowodrza } & Prądnik Biały & $\begin{array}{l}19 \text { - Krowodrza Wsch., } 20 \text { - Krowodrza Pn., } 21 \text { - Azory Wsch., } 22 \text { - Azory Zach., } \\
23 \text { - Pradnik Biały Pd., } 24 \text { - Witkowice-Górka Narodowa Wsch., } 25 \text { - Witkowice- } \\
\text { Górka Narodowa Zach, } 26 \text { - Pradnik Biały Pn., } 27 \text { - Tonie, } 28 \text { - Bronowice Wielkie }\end{array}$ \\
\hline & Krowodrza & $\begin{array}{l}29 \text { - Błonia, } 30 \text { - Czarna Wieś, } 31 \text { - Nowa Wieś Pd., } 32 \text { - Krowodrza - Nowa } \\
\text { Wieś, } 33 \text { - Krowodrza Pd., } 34 \text { - Małe Błonie }\end{array}$ \\
\hline & Bronowice & $\begin{array}{l}35 \text { - Bronowice Małe Wsch., } 36 \text { - Widok, } 37 \text { - Bronowice Małe Pn., } 38 \text { - Brono- } \\
\text { wice Małe Pd., } 39 \text { - Mydlniki Pd., } 40 \text { - Mydlniki Pn. }\end{array}$ \\
\hline & Zwierzyniec & $\begin{array}{l}41 \text { - Półwsie Zwierzynieckie, } 42 \text { - Zwierzyniec, } 43 \text { - Przegorzały Wsch., } \\
44 \text { - Przegorzały-Zwierzyniec, } 45 \text { - Przegorzały Pd., } 46 \text { - Przegorzały Pn., } \\
47 \text { - Wola Justowska - Chełm, } 48 \text { - Las Wolski, } 49 \text { - Bielany, } 50 \text { - Olszanica }\end{array}$ \\
\hline \multirow{6}{*}{ Podgórze } & Dębniki & $\begin{array}{l}51 \text { - Dębniki, } 52 \text { - Ludwinów, } 53 \text { - Dębniki Zach., } 54 \text { - Zakrzówek, } 55 \text { - Pycho- } \\
\text { wice, } 56 \text { - Kobierzyn, } 57 \text { - Bodzów, } 58 \text { - Skotniki, } 59 \text { - Sidzina, } 60 \text { - Olszyny, } \\
61 \text { - Tyniec, } 62 \text { - Kostrze }\end{array}$ \\
\hline & $\begin{array}{l}\text { Łagiewniki - Borek } \\
\text { Fałęcki }\end{array}$ & $\begin{array}{l}63 \text { - Cegielniana, } 64 \text { - Łagiewniki, } 65 \text { - Borek Fałęcki Zach., } 66 \text { - Borek Fałęcki } \\
\text { Wsch. }\end{array}$ \\
\hline & Swoszowice & $\begin{array}{l}67 \text { - Kliny, } 68 \text { - Jugowice, } 69 \text { - Opatkowice Zach., } 70 \text { - Opatkowice Wsch., } \\
71 \text { - Swoszowice, } 72 \text { - Wróblowice, } 73 \text { - Zbydniowice, } 74 \text { - Rajsko-Soboniowice, } \\
75 \text { - Kosocice }\end{array}$ \\
\hline & $\begin{array}{l}\text { Podgórze } \\
\text { Duchackie }\end{array}$ & 76 - Wola Duchacka Zach., 77 - Wola Duchacka Wsch., 78 - Kurdwanów, 79 - Piaski \\
\hline & \begin{tabular}{|l|} 
Bieżanów - \\
Prokocim \\
\end{tabular} & $\begin{array}{l}80 \text { - Stary Prokocim, } 81 \text { - Kozłówek, } 82 \text { - Nowy Prokocim, } 83 \text { - Rżaka, } 84 \text { - Nowy } \\
\text { Bieżanów, } 85 \text { - Bieżanów Kolonia, } 86 \text { - Stary Bieżanów }\end{array}$ \\
\hline & Podgórze & $\begin{array}{l}87 \text { - Bonarka, } 88 \text { - Mateczny, } 89 \text { - Stare Podgórze, } 90 \text { - Zabłocie, } 91 \text { - Kopiec } \\
\text { Krakusa, } 92 \text { - Płaszów, } 93 \text { - Kabel, } 94 \text { - Heltmana, } 95 \text { - Zarzecze, } 96 \text { - Podgaje, } \\
97 \text { - Rybitwy, } 98 \text { - Przewóz }\end{array}$ \\
\hline \multirow{5}{*}{ Nowa Huta } & Czyżyny & $\begin{array}{l}99 \text { - Czyżyny Lotnisko, } 100 \text { - Czyżyny Park, } 101 \text { - Czyżyny, } 102 \text { - Beszcz, } \\
103 \text { - Czyżyny Łęg }\end{array}$ \\
\hline & Mistrzejowice & 104 - Mistrzejowice, 105 - Batowice \\
\hline & Bieńczyce & 106 - Os. Albertyńskie, 107 - Bieńczyce Nowe, 108 - Bieńczyce Stare \\
\hline & $\begin{array}{l}\text { Wzgórza } \\
\text { Krzesławickie }\end{array}$ & $\begin{array}{l}109 \text { - Zesławice, } 110 \text { - Wzgórza Krzesławickie, } 111 \text { - Krzesławice, } \\
112 \text { - Grębałów, } 113 \text { - Kantorowice, } 114 \text { - Lubocza, } 115 \text { - Łuczanowice-Wadów, } \\
116 \text { - Węgrzynowice }\end{array}$ \\
\hline & Nowa Huta & $\begin{array}{l}117 \text { - Spółdzielcze-Kolorowe, } 118 \text { - Teatralne, } 119 \text { - Krakowiaków-Górali, } \\
120 \text { - Sportowe-Zielone, } 121 \text { - Szkolne, } 122 \text { - Stalowe-Willowe-Wandy, } \\
123 \text { - Urocze, } 124 \text { - Słoneczne, } 125 \text { - Centrum D-Handlowe, } 126 \text { - Centrum } \\
\text { C-Zgodny, } 127 \text { - Centrum B-Szlkane Domy, } 128 \text { - Centrum A-Hutnicze Ogro- } \\
\text { dowe, } 129 \text { - Na Skarpie, } 130 \text { - Mogiła, } 131 \text { - Ogródki, } 132 \text { - Kombinat HTS, } \\
133 \text { - Mogiła Wsch., } 134 \text { - Pleszów Kujawy, } 135 \text { - Branice, } 136 \text { - Ruszcza, } \\
137 \text { - Wyciąże Zach., } 138 \text { - Przylasek Rusiecki, } 139 \text { - Wolica-Przylasek Rusiecki, } \\
140 \text { - Wyciąże Wsch., } 141 \text { - Kościelniki }\end{array}$ \\
\hline
\end{tabular}

Source: data from the Kraków City Office 